\section{Access to gambling among Brazilian adolescents: why should we care?}

Acesso a jogos de azar em adolescentes
brasileiros: por que devemos nos preocupar?

Dear Editor,

It is well known that adolescents are more vulnerable to the negative effects of gambling and need to be protected. ${ }^{1}$ Recent studies conducted in developed countries using nationally representative samples have shown that $60 \%$ to $80 \%$ of adolescents gambled in the previous year and $0.9 \%$ to $3.1 \%$ meet criteria for pathological gambling (PG).,2,3

Although the relationship between access to gambling and gambling related problems is not linear, the majority of studies have shown that the easier the access, the higher the risk for problem gambling. Government permissiveness (usually measured by the number of betting modalities legally accepted) and geographical proximity from individuals to gambling places ${ }^{4}$ are risk factors contributing to this issue.

In 1993 the Brazilian government approved a federal law that legalized bingo. The aim was to foster sports without diverting money from other priorities. However, loopholes in the law opened the door for electronic bingo and EGMs. At the same time, clandestine EGMs were easily found in bars, restaurants and cafeterias. Nowadays bingo and electronic bingo are once again forbidden. It may be possible to slow the process of gambling expansion, but it is likely to be irreversible since the majority of EGMs operate underground and new poker houses have been opened in different urban sites around the country. Due to the lack of data supporting a better understanding of gambling and its consequences in Brazil, laws will still be predominantly based on economic interests.

Data from the Brazilian National Alcohol Survey, the first study evaluating the prevalence of $P G$ among a nationally representative sample of Brazilian adolescents, are under analysis. A multistage cluster sampling procedure was used to select 3,007 individuals over 14 years of age from the Brazilian household population. Face to face interviews were conducted in respondents' homes by trained interviewers using a standardized closed questionnaire. A total of 661 participants took part, aged between 14 and 17 years old. 4,5

Preliminary results surprisingly have demonstrated that, although the prevalence of PG was similar to international studies, 93\% (standard error $=1.1 \%$ ) of Brazilian adolescents denied gambling participation, i.e. only $7 \%$ of Brazilian adolescents reported gambling.

This difference could be explained by the fact that in countries where gambling is legalized, young people are highly exposed to gambling and its promotion on a daily basis. However, it is also possible that methodological variations regarding the instrument used in this study might account for some of these differences. Due to time limitations the questionnaire used did not take into consideration specific questions regarding participation in different types of gambling and when this occurred (last month, last year or lifetime).

These findings lead us to two important questions:
1) Which factors other than gambling access are related to $P G$ in Brazil?

2) What will happen to $P G$ prevalence if gambling access and participation keep rising?

A major concern is that a number of factors in our country may negatively influence the relationship between adolescents and gambling. The government runs the lottery, which aside from horse racing is the only legal gambling activity. Colluding with the gambling industry may lower government supervision of betting. ${ }^{6}$ Besides, one of the country's major challenges still is the distribution of wealth, and it is a fact that poverty, unemployment and low income are risk factors for PG. ${ }^{7}$ So far there is no public policy regarding the protection of vulnerable individuals and prevention of gambling problems.

Daniel Tornaim Spritzer

Psychiatry Post-Graduate Program, Universidade Federal do Rio Grande do Sul (UFRGS), Porto Alegre (RS), Brazil

Ronaldo Laranjeira, Ilana Pinsky

Psychiatry Department, Universidade Federal de São Paulo (UNIFESP), São Paulo (SP), Brazil Marcos Zaleski
Universidade Federal de Santa Catarina (UFSC),
Florianópolis (SC), Brazil

Raul Caetano

Houston Health Science Center, University of Texas, Dallas, Texas, USA

Hermano Tavares

Department of Psychiatry, Universidade de São Paulo (USP), São Paulo (SP), Brazil 
Disclosures

\begin{tabular}{|c|c|c|c|c|c|c|c|}
\hline $\begin{array}{l}\text { Writing group } \\
\text { member }\end{array}$ & Employment & Research grant $^{1}$ & $\begin{array}{l}\text { Other research grant } \\
\text { or medical continuous } \\
\text { education }^{2}\end{array}$ & $\begin{array}{l}\text { Speaker's } \\
\text { honoraria }\end{array}$ & $\begin{array}{l}\text { Ownership } \\
\text { interest }\end{array}$ & $\begin{array}{l}\text { Consultant/ } \\
\text { Advisory } \\
\text { Board }\end{array}$ & Other $^{3}$ \\
\hline $\begin{array}{l}\text { Daniel Tornaim } \\
\text { Spritzer }\end{array}$ & UFRGS & - & - & - & - & - & - \\
\hline $\begin{array}{l}\text { Ronaldo } \\
\text { Laranjeira }\end{array}$ & UNIFESP & $\begin{array}{l}\text { FAPESP }^{* *} \\
\text { CNPq }^{* * *}\end{array}$ & - & - & - & - & - \\
\hline Ilana Pinsky & UNIFESP & FAPESP** & - & - & - & - & - \\
\hline Marcos Zaleski & UFSC & SENAD & - & - & - & - & - \\
\hline Raul Caetano & $\begin{array}{c}\text { University of } \\
\text { Texas }\end{array}$ & $\mathrm{NIAAA}^{* * *}$ & - & - & - & - & - \\
\hline Hermano Tavares & $\begin{array}{c}\text { USP* }^{*} \\
\text { ANJOTI* }^{*}\end{array}$ & FAPESP** & - & $\begin{array}{l}\text { Jansen-Cilag* } \\
\text { Instituto } \\
\text { Américo Bairral }\end{array}$ & - & - & $\begin{array}{c}\text { Lundbeck* }^{*} \text { Servier }^{*} \\
\text { Roche }^{*} \\
\text { Apsen*} \\
\text { Wyeth* }^{*} \\
\text { Sandoz }^{*} \\
\text { Abbott* } \\
\text { Cristália } \\
\text { Editora Artes } \\
\text { Médicas } \\
\text { TAM Linhas } \\
\text { Aéreas }\end{array}$ \\
\hline \multicolumn{8}{|c|}{$\begin{array}{l}\text { *Modest } \\
\text { ** Significant } \\
\text { *** Significant. Amounts given to the author's and institution or to a colleague for research in which the author has participation, not directly to the author. } \\
\text { Note: UFRGS = Universidade Federal do Rio Grande do Sul; UNIFESP = Universidade Federal de São Paulo; UFSC = Universidade Federal de Santa Catarine } \\
\text { FAPESP = Fundação de Amparo à Pesquisa do Estado de São Paulo; CNPq = Conselho Nacional de Desenvolvimento Científico e Tecnológico; SENAD } \\
\text { Secretaria Nacional de Politicas sobre Drogas; NIAAA = National Institute on Alcohol Abuse and Alcoholism; USP = Universidade de São Paulo; ANJOTI } \\
\text { Associação Nacional do Jogo Patológico e Outros Transtornos do Impulso. } \\
\text { For more information, see Instructions for authors. }\end{array}$} \\
\hline
\end{tabular}

References

1. Orford J. Disabling the public interest: gambling strategies and policies for Britain. Addiction. 2005;100(9):1219-25.

2. Wardle H, Sproston K, Orford J, Erens B, Griffiths M, Constantine R, Pigott S. British Gambling Prevalence Survey 2007. London: The UK Gambling Commission; 2007.

3. Hansen M, Rossow I. Adolescent gambling and problem gambling: does the total consumption model apply? J Gambl Stud. 2008;24(2):135-49.

4. Pechansky F, De Boni R, Diemen LV, Bumaguin D, Pinsky I, Zalesk M, Caetano R, Laranjeira R. Highly reported prevalence of drinking and driving in Brazil: data from the first representative household study. Rev Bras Psiquiatr. 2009;31(2):125-30.

5. Laranjeira R, Pinsky I, Zalesky M, Caetano R. I Levantamento Nacional sobre os padrões de consumo de álcool na população brasileira. Secretária Nacional Antidrogas - SENAD: Brasília, DF; 2007.

6. Robitaille $E$, Herjean P. An analysis of the accessibility of video lottery terminals: the case of Montréal. Int J Health Geogr. 2008;7:2.

7. Raylu N, Oei TP. Role of culture in gambling and problem gambling. Clin Psychol Rev. 2004;23(8):1087-114. 